\title{
Introduction: Beyond Foucault: Excursions in Political Genealogy
}

\author{
Michael Clifford \\ Department of Philosophy and Religion, Mississippi State University, Mississippi State, MS 39762, USA; \\ Mrc4@msstate.edu
}

Received: 30 August 2018; Accepted: 5 September 2018; Published: 5 September 2018

The essays in this volume were submitted for a special issue of the new journal, Genealogy, on the theme, "Political Genealogy After Foucault." Inspired by the work of Michel Foucault, this volume includes articles from scholars employing political genealogy as a methodology and model of theoretical inquiry representing a wide range of disciplines, from the social sciences to the humanities, from philosophy to medicine to economics to political and cultural theory. The goal of this volume is to publish some of the best and most current work in political genealogy, showing how this work invites us to rethink many of the key concepts in political theory as well as cultural types of expression that we do not routinely think of as political, such as dance, romantic movies, and literature. Broadly conceived, this volume contains essays-excursions, explorations, experimentations-into how political genealogy helps us to understand what Foucault calls "the history of our present," while at the same time looking to our future, to what being a political subject will look like in the 21st century.

The geographical diversity of the authors is remarkable. They come from the United States, Canada, England, Finland, Lithuania, Australia, and Hong Kong. This diversity reflects not only the international influence of Foucault, but, more importantly, the intellectual range of the authors, their ability to mine the potential of political genealogy and to generate their own unique contributions and creations. The topical diversity of the papers is equally impressive-on Trump and Trumpism, popular culture and ideology, political identity and personhood, sovereignty, genealogy and ethics, heroism and cowardice in 21st century warfare, governmentality and chronic illness, even intellectual property. This is a testament to the potential and real fecundity of political genealogy.

This is not a homage to Foucault. Nor a critique of Foucault. It is certainly not a Baudriallardian attempt to "forget" Foucault (Baudriallard 2007). These are excursions, from the Latin, excurrere, or "running out", not in the sense of exhausting something, but of finding a new path. Going beyond Foucault means finding new paths, new outlets, sorties exploring the potential of genealogy, as understood and elaborated upon by Foucault, ones which deviate from the usual routes in order to find new pathways, new avenues of exploration, of finding and addressing issues and concerns not yet investigated.

Inspiration is never sui generis. Sometimes it springs from the beautiful, the sublime, or the merely practical. Sometimes, it arises from something latent, not quite realized. The authors in this volume have at least this much in common: they are all inspired by the mode of enquiry that stems from Foucault's work on political genealogy.

Elsewhere I have argued that a viable methodology, one whose main focus is on political genealogy, could be generated by bringing together the three main movements of Foucault's thought (Clifford 2001). Although there is no clear separation between these movements either chronologically or thematically, they include his early "archaeological" analysis of discourse and discursive regimes (Foucault 1972, 1973), his later work, a more explicitly "genealogical" study of power/knowledge relations and governmentality (Foucault 1979), and finally his examination of 
processes of subjectivation, a move he often referred to, somewhat idiosyncratically, as "ethics," focusing on sexuality (Foucault 1982, 1985). With respect to the application of the latter, in his essay here entitled, "Heroes and Cowards: Genealogy, Subjectivity and War in the Twenty-First Century," Peter Lee conducts a study of the ethical subjects of war, specifically, the hero and coward, and how they are self-constituted in the contemporary era in the forms of the drone operator vs. the jihadist (Lee 2018). Genealogy makes it possible to better understand the ethical subjectivity of Islamic terrorists by concentrating on the "moral basis of their actions; their justifications for killing non-combatants and the relationship between" religion and violence. By the same token, genealogy reveals "a deeper understanding of the subjectivity of the drone operator who conducts lethal operations." There is a certain mutuality of self-constitution on the part of the jihadist and the drone operator, an agonistic relationship through which the heroism or cowardice of the other is seen through their respective prisms of what constitutes a just war and of how they understand themselves as respective participants in such a war.

Lee's analysis is similar to that conducted by Engin Isin on the relational character between citizens and non-citizens (Isin 2002). Says Isin, "Citizenship and its alterity always emerged simultaneously in a dialogical manner and constituted each other." According to Isin, what we call groups, whether dominant or dominated, are better understood as "projects" of citizenship. These projects involve strategies which are solidaristic, enjoining individuals under a mantle of likeness and identity, or antagonistic, wherein these same individuals orient themselves to others as outsiders or strangers. But the dialogical character of this process means that both the dominant group and the dominated group are mutually constituted through the very same gestures. Like Lee, Isin sees these projects of identity formation as reflective of what Foucault's calls technologies of the self. These technologies, says Isin, enable "individuals to effect by their own means or with others a certain number of operations on their own bodies and souls, thoughts and conduct, so as to transform themselves." Through such processes, individuals transform themselves into identities, such as the citizen and the non-citizen, or, for example, "the heroic war-hero of the Greek polis" and the slave boy, who helps the charioteer in his rigorous training but who himself is not allowed to take part in such training —or, as Lee demonstrates, the jihadist and the drone operator.

The question of identity is central to Foucault's work and to genealogy more generally. Rather than assuming a metaphysically given Cartesian self or identity, genealogy brings about "the systematic disassociation of identity," says Foucault (Foucault 1977). The purpose of genealogy, if we can characterize it that way, "is not to discover the roots of our identity, but to commit itself to its dissipation." Nevertheless, effecting this kind of deconstruction involves tracing the "roots" of identity, not in the sense of discovering its ontological origin, but of revealing the historical contingencies of its emergence. Here, in her essay, "Persons and Sovereigns in Ethical Thought," Ladelle McWhorter does exactly that with her analysis of the notion of personhood (McWhorter 2017). She reveals the historical emergence of personhood in the 17th century, and how it was originally used as a tool of oppression. Like Foucault, she anticipates a future when personhood will disappear and thereby open up new possibilities for ethical and political selfhood.

From the cult of personality to the origins of personhood itself, McWhorter's and Bruce Knauft's essays are like bookends enclosing the vexing problem of modern political identity. In his essay here called, "On the Political Genealogy of Trump After Foucault," Knauft discusses how Trump and Trumpism have cast a huge shadow over the political and cultural landscape (Knauft 2018). Trumpism has taken or coincided with many forms, which include a rabid populism, xenophobia, and anti-intellectualism, observes Knauft. In what Time magazine has called a "post-truth" era, in which "fake news" and "alternative facts" have gained unprecedented traction, the very discourse of political engagement has been transformed at a dizzying rate. At the time of this writing, Trump has been implicated in illegal campaign contributions, but it is not clear what the outcome will be for the Trump presidency or the country, given that the norms of political discourse and political practice have been altered so dramatically. Knauft traces out the potential ramifications for this new era. 
Donald Trump is a mask, the mask of "Donald Trump," a simulacrum, the image of an image(s) — of the billionaire, of the brand, of a television celebrity playing the billionaire, who fires people, the act itself an embellishment of the brand, now, however unlikely, the President of the United States, or the simulacrum of such, like the auto-animatronic figures in Disney's Hall of Presidents. In some ways, Trump is not unlike the figure of Jeremy Bentham, who sits in a huge mahogany box in the hallway at the University of London. This "auto-icon" is witness to the parade of students on their way to class. Imagine if a wax figure (actually only the head is made of wax-the clothes cover Bentham's actual bones) like this were to come to life, orange-faced, hair plastered over in a yellow mash, raised to the pedestal of the highest office in the land. How could we not be transfixed, with reverence or revulsion, by this figure, this personage, this auto-icon? What does this say about the inter-emersion of the cultural "colonization of consciousness," as Knauft puts it, of kitsch personified, to extend Bielskis's analysis reprinted here, as well (Bielskis 2018), of the infiltration and mutual empowerment of neo-liberalism into the media, of 21st century subjectivity itself. We are tempted to say that our identities have been co-opted, but that presupposes a pre-given, foundational self, as McWhorter shows, something which is revealed to be a kind of illusion, a kind of mask, by the harsh, subversive light of genealogy.

Political genealogy can also be deployed to illuminate the political dimensions of aesthetic aspects of the cultural landscape, such as dance and literature. Genealogies, of course, render the past intelligible in ways that are disruptive of the present and which thereby alter our future. In a sense, there is a kind of dance between what Heidegger and Sartre called the "temporal ekstases" of past, present, and future. And the genealogist is the choreographer. This metaphor of the dance informs Julian Reid's political genealogy here of actual dance, focusing on the groundbreaking work of such dancers as Loïe Fuller, in his essay, "A Political Genealogy of Dance: The Choreographing of Life and Images." (Reid 2018)

This brings to mind Nietzsche's exhortation that one needs to have chaos in one's soul to give birth to a dancing star. Dance plays with the chaotic, gives it shape and form. As such, the chaotic is chiaroscuric. It plays with light and darkness, with absence and presence, movement and stasis, birth and death. There is also form, a tenuous unity in chaos/chiaroscuro-that form is necessarily political in the way that Reid describes it. Dance "can be understood to be deeply political," says Reid, because it "transform[s] by creating time for a belief in the impossible." Dance is a discourse of sorts, a discourse with a history, with a set of norms and rules, "aims and practices," which at once demand compliance, but in so doing herald their own transgression. Along the way its suspends and elevates, "reawakening [the] political imagination in times of crisis and neoliberal hegemony."

Foucault had an ambiguous relationship/attitude toward neoliberalism. It is against this backdrop that Riccardo Baldissone stages a "re-reading" of Foucault's formative essay, "Nietzsche, Genealogy, History." (Foucault 1977). In his essay reprinted here, "Foucault and Foucault: Following in Pierre Menard's Footsteps" (Baldissone 2018), Baldissone adopts a gesture similar to that taken up by Borges, in his "recomposition" of Cervantes' Don Quijote. In so doing, Baldissone offers a reading of Foucault that demonstrates the equivocal character of Foucault's relationship toward neoliberalism that compels us to re-think the Foucauldian, and Nietzschean, consequences for the political, and genealogy, more generally.

What is meant by "political genealogy" as a methodology and a form of historical critique? (See Clifford 2013) It is genealogical in the sense that Nietzsche and Foucault use the term: an historical critique that traces the forgotten origins of our present, including, but not limited to, the institutions of government and the forms of identity constructed therein. There are at least two senses in which genealogy is political. One is with respect to the object of inquiry, in that it focuses on the established ideas and institutions of traditional political theory, namely, government, power, freedom, representation, rights, justice, and so on. However, as I said, it also focuses on areas not immediately recognized as political. Genealogy questions the privilege of these ideas by suggesting that there are areas of inquiry, as demonstrated in this collection, that have not only been overlooked or discounted 
by conventional political theory, but that in fact have dramatic consequences for the traditional areas mentioned above. In this sense, the aim of political genealogy is, to use the words of Nikolas Rose, "to reshape and expand the terms of political debate, enabling different questions to be asked, enlarging the space of legitimate contestation" (Rose 1999).

Political genealogy is political, secondly, in its effects. By revealing the historical contingency of established values and practices, genealogy destabilizes the mechanisms through which we are governed. Genealogy empowers modes of contestation not previously available to political subjects. For this reason, Nietzsche thought of genealogy as "therapeutic" in that it exposes the decadence of entrenched value systems. Similarly, Foucault describes a kind of "counter-memory" that emerges from genealogical critique, through which the power of a given set of beliefs about, for example, how things should be done or the nature of our identity as political subjects, is suspended. In the space opened up by this suspension, a certain kind of freedom is made possible, minimally the recognition that things might be otherwise, which can serve as an impetus to political change. (See, McWhorter 2017)

The project-or more appropriately, projects-in the larger sense, of which the essays published here are exemplars, of political genealogy is to piece together a critical methodology based on the genealogical model that can be applied to the political, both the conceptual and the practical. This methodology is strictly speaking neither Nietzschean nor Foucauldian, although it draws from both thinkers as its conceptual wellspring. Or rather, it is Nietzschean and Foucauldian in that both represent the source of the methodology, and to the extent that the methodology cannot be separated from the corpus of either thinker. Yet it is not meant as a simple recapitulation of their views; nor is it primarily, or even secondarily, a critical analysis or evaluation of their respective genealogies.

The projects here might be referred to as examples of "poligen studies" (see Clifford 2013). The term "poligen" comes from the collapse into a single term of political genealogy. The term is analogically connected to its cousin in biology, the polygenic. In biology, the polygenic refers to the inheritance of traits from multiple, often unknown factors. Similarly, the history of the present conducted by genealogy attempts to reveal those hidden multiple factors contributing to the identity of the present, and to the identities populating the present.

Moreover, as Réal Fillion shows in his essay reprinted here, "Situating Poligen Studies: Between Moral Enquiry and Political Theory", (Fillion 2017), there is both a moral and political aspect to poligen studies. Says Fillion, "Another way to say this is that situating the pursuit of poligen studies between moral enquiry and political theory is to recognize that these struggles and resistances themselves express the moral refusal of the ordering constraints being imposed on the struggling and resisting agents subject to them." This moral dimension of poligen studies is not just an exploration of the historical constitution of the self through what Foucault calls an ethics of subjection, which is meant to be neutral with respect to understanding the identities that are formed through the self-appropriation of values. There is a normative dimension to political genealogy that Foucault may or may not have been happy with supporting. Nevertheless, poligen studies have the effect of disrupting established modes of subjection, empowering subjects to resist, with the implied assumption that things, even one's very identity, might be different than they presently are. Difference, differing is itself intrinsically political and inherently moral, by virtue of the stance it makes possible in the face of entrenched power relations. This means in part acknowledging and to some degree facilitating the potential of a genealogical critique on the practical lives of individuals. Moreover, the genealogical emphasis on local knowledge and experience forces us to contend with real-world instantiations of justice, power, and freedom. In so doing, these ideas typically undergo a transformation sometimes at odds with their traditional ideological and philosophical meanings. That is, on the ground, in the trenches, genealogical analysis reveals the true meaning, the meaning in praxis, of justice, power, and freedom for those whose very identity is a product of practices, policies, and institutions that operate according to a different logic, a different agenda than that prescribed by the traditional juridical discourse of political representation. 
Despite the diversity of approaches, these essays have two very important things in common. One, a certain understanding of political genealogy as a method and what it can facilitate and, second, a commitment to the application of that method to real issues and problems beyond a critique of Foucault, to the extent that the two can be separated. To wit, with regard to method, Wendyl Luna says, in his essay here on intellectual property, "Foucault's genealogy provides a useful and still relevant approach to analyzing rights and power, especially in the specific context of [intellectual property]" (Luna 2018). Lee echoes this sentiment: "Political genealogy after Foucault can open up a conceptual space that will provide a more nuanced understanding of subjectivity in modern war." Ann Reich and Margo Turnbull bring a Foucauldian -inspired methodology to the understanding of the power relations related to disease, saying that, in their project "the genealogical approach informed by Foucault facilitated a unique tracing of the dominant discourses and practices circulating in the local, national and global contexts and linkages to the day-to-day lives of the clients with chronic diseases," (here in "Using Foucault: Genealogy, Governmentality and the problem of Chronic Illness," (Reich and Turnbull 2018)).

On the other hand, to say that Foucault has a method which can be straightforwardly adopted and applied should be tempered with a healthy degree of caveats and cautions. Says Andrius Bielskis, "We should not understand Foucault's genealogy as a heavy-handed theoretical methodology with deductively established first principles, which are then applied to the analysis of existing power relations and social institutions." "On the Genealogy of Kitsch and Critique of Ideology: A Reflection on Method," (Bielskis 2018); reprinted here.) As Foucault himself says, observes Bielskis, he considers himself more of an "experimenter" than a theorist. Applying political genealogy is more of an experiment, an excursion, if you will, into areas of the political, social, and cultural in ways that have previously been overlooked or never considered. Reich and Turnbull are even more blunt about the limitations of political genealogy as a method: "As a 'method' for analyzing contemporary problems, readings of Foucault's work have revealed that there is no clearly stated, well-defined or prescribed methodology for investigations."

Generally speaking, when it comes to theory/methodology/application, there is no clear demarcation. Thinkers as diverse as Leo Strauss and Baudrilliard have questioned the distinction between theory and it is application. The mediator between the two is arguably considered to be methodology, but here, too, the lines are blurred, such that it is not clear where one leaves off and the other begins. In one sense, this is not all surprising, since the mediation between theory and practice - notably understood as "praxis" in Marxist camps and beyond-is fluid. Not surprisingly, Foucault is suspicious of the separation between theory and practice. For him, the distinction is another of the numerous dichotomies shaping Western thought. Which puts the projects of the essays in this collection in something of a precarious position, since they ostensibly rely on these very dichotomies. Perhaps we need to allow the authors their points of departure, their modes of execution, their conclusions, and sort out the differences between theory, methodology, and application later. After all, what counts with genealogies is not so much the truth of their expositions (since "truth" itself is problematized and historicized by genealogy), but the effects of these excursions on how we think and how we live.

Funding: This research received no external funding.

Conflicts of Interest: The author declares no conflicts of interest.

\section{References}

Baldissone, Riccardo. 2018. Foucault and Foucault: Following in Pierre Menard's Footsteps. Genealogy 2: 19. [CrossRef]

Baudriallard, Jean. 2007. Forget Foucault. Los Angeles: Semiotexte.

Bielskis, Andrius. 2018. On the Genealogy of Kitsch and the Critique of Ideology: A Reflection on Method. Genealogy 2: 9. [CrossRef] 
Clifford, Michael. 2001. Political Genealogy after Foucault: Savage Identities. New York and London: Routledge Press.

Clifford, Michael. 2013. Empowerment: The Theory and Practice of Political Genealogy. Lanham: Lexington/Rowan \& Littlefield.

Fillion, Réal. 2017. Situating Poligen Studies: Between Moral Enquiry and Political Theory. Genealogy 2: 2. [CrossRef]

Foucault, Michel. 1972. The Archaeology of Knowledge and the Discourse on Language. Translated by A. M. Sheridan Smith. New York: Pantheon.

Foucault, Michel. 1973. The Order of Things: An Archaeology of the Human Sciences. New York: Vintage Books.

Foucault, Michel. 1977. Language, Counter-Memory, practice, ed. Edited by Donald Bouchard. Ithaca: Cornell University Press.

Foucault, Michel. 1979. Discipline and Punish: The Birth of the Prison. Translated by Alan Sheridan. New York: Vintage Books.

Foucault, Michel. 1982. On the Genealogy of Ethics: An Overview of Work in Progress. In Michel Foucault: Beyond Structuralism and Hermeneutics, 2nd ed. Edited by Hubert L. Dreyfus and Paul Rabinow. Chicago: University of Chicago Press.

Foucault, Michel. 1985. The Use of Pleasure: Volume 2 of the History of Sexuality. Translated by Robert Hurley. New York: Pantheon Books.

Isin, Engin F. 2002. Being Political: Genealogies of Citizenship. Minneapolis: University of Minnesota Press.

Knauft, Bruce M. 2018. On the Political Genealogy of Trump after Foucault. Genealogy 2: 4. [CrossRef]

Lee, Peter. 2018. Heroes and Cowards: Genealogy, Subjectivity and War in the Twenty-First Century. Genealogy 2: 15. [CrossRef]

Luna, Wendyl. 2018. Emancipating Intellectual Property from Proprietarianism: Drahos, Foucault, and a Quasi-Genealogy of IP. Genealogy 2: 6. [CrossRef]

McWhorter, Ladelle. 2017. Persons and Sovereigns in Ethical Thought. Genealogy 1: 24. [CrossRef]

Reich, Ann, and Margo Turnbull. 2018. Using Foucault: Genealogy, Governmentality and the Problem of Chronic Illness. Genealogy 2: 13. [CrossRef]

Reid, Julian. 2018. A Political Genealogy of Dance: Choreographing of Life and Images. Genealogy 2: 20. [CrossRef] Rose, Nikolas. 1999. Powers of Freedom: Reframing Political Thought. Cambridge: Cambridge University Press.

(C) 2018 by the author. Licensee MDPI, Basel, Switzerland. This article is an open access article distributed under the terms and conditions of the Creative Commons Attribution (CC BY) license (http:/ / creativecommons.org/licenses/by/4.0/). 